\title{
Fraud Intention and Machiavellianism: An Experimental Study of Fraud Triangle
}

\author{
Intiyas Utami ${ }^{1}$, Yosephine Widwining Astiti ${ }^{1} \&$ Nafsiah Mohamed $^{2}$ \\ ${ }^{1}$ Faculty of Business and Economics, Satya Wacana Christian University, Indonesia \\ ${ }^{2}$ Accounting Research Institute, Universit Teknologi MARA, Malaysia \\ Correspondence: Nafsiah Mohamed, Accounting Research Institute Universit Teknologi MARA, Malaysia.
}

Received: April 30, 2019

doi:10.5430/ijfr.v10n5p269
Accepted: May 30, 2019

Online Published: June 11, 2019

URL: https://doi.org/10.5430/ijfr.v10n5p269

\begin{abstract}
This study aims to examine the causal relationships between fraud triangle and Machiavellianism and fraud intention. Besides the fraud triangle components (pressure, opportunity, and rationalization), Machiavellianism and fraud intention also likely affect fraud. We run our experimental study at several Indonesian universities and use undergraduate accounting students as our subjects. Further, this study uses a 3x2x2 experimental design with 309 students as the subjects acting as purchasing managers. The results show that 1) individuals with high life pressure exhibit greater fraud intention than individuals with low life pressures, 2) individuals who are in a weak internal control condition have greater fraud intention than individuals who are in strong internal control conditions, 3) individuals with high rationalization of fraud have greater fraud intention than individuals with low rationalization, and 4)individuals with high Machiavellianism exhibit greater fraud intention than individuals with low Machiavellianism.
\end{abstract}

Keywords: pressure, opportunity, rationalization, Machiavellianism

\section{Introduction}

Fraud is a commonly found act of crime. Priantara (2013) explains that fraud, along with terrorism, is a crime that receives great public attention. ACFE (The Association of Certified Fraud Examiners) (2018) claims that corruption is one of the most significant fraud risks for most organizations and regions. Besides the fraud triangle, a likely factor that causes fraud is a Machiavellian attitude (Ghosh and Crain, 1996). Zin et al., (2011) argue that Machiavellianism is one's personality that is related to the concept of the acquisition and use of power in engaging various manipulations. Employees who have higher needs to develop and maintain power and success. Individuals with strong drives for success tend to commit actions that benefit them. Individuals' enthusiasm in organizations affects the achievement of organizational goals. Further, a Machiavellian is an individual who lacks conventional morality and exhibits emotional detachment behavior and a tendency to manipulate people and situation (Christe \& Geis, 1970). In general, individuals can be classified into two categories (high Mach vs. low Mach) based on their orientation on the situations. Machiavellianism is an individual's personality trait that tends to have great needs to develop and maintain power and success. Individuals with high Mach are associated with antisocial behaviors and focus on extrinsic goals, especially financial success (Tang 2008; Mbunda-Nekang, 2018). Thus, high Machiavellianism will result in greater unethical behavior than low Machiavellianism (Gunnthorsdottir et al., 2002). A form of unethical behavior is fraudulent behavior.

The previous study of Abdullahi and Mansor (2015) focuses on fraud triangle and fraud diamond. The internal factors that cause fraud are pressure and rationalization while opportunity is the external factor. Meanwhile, Hartmann dan Maas (2010) suggest fraudulent behavior in the management context is affected by the Machiavellian attitude that can be measured into two levels, namely high and low Mach levels. Individual machiavellian attitude then likely affects fraudulent behavior in the corruption context. This study aims to test the causal relationship between fraud triangle and Machiavellianism with fraud intention. Thus, this study contributes to the accounting and business literature by demonstrating the effects of fraud triangle and Machiavellianism factors on accounting students' fraud intention. Further, the practical contribution of this study is motivating and informing accounting program to avoid fraudulent behavior and to become highly ethical public accountants with a high moral standard. 


\section{Theoretical Review}

\subsection{Fraud and Fraud Intention}

ACFE (2016) claims that fraud is a continuously evolving problem nowadays. Fraud is not only committed by upper-level personnel, but also by middle-level and even lower-level ones. Rezaee (2005) defines fraud as an intentional act by an entity that results in the ownership of an illegal gain. Clinard and Cressey (1954) explain the three fraud items that are usually presented as a triangle diagram. These three items in the triangle diagram are pressure, opportunity, and rationalization (Houck et al., 2006; Michael, Justina \& Olabode 2018).

\subsection{Pressure}

Pressure refers to factors that trigger unethical behaviors. Each fraudster faces pressure to commit unethical behavior (Abdullahi and Mansor, 2015). Lister (2007) suggests that pressure is a starting point of a fraud incident. Individuals with high life pressure tend to exhibit greater fraud intention than individuals with low life pressure.

\subsection{Opportunity}

A potential fraudster obtains an opportunity to commit fraud from an ineffective control or a governance system that enables this individual to commit organizational fraud. In accounting, such ineffective control is labeled as an internal control weakness. Several factors cause greater opportunities for employees to commit fraud in their organizations such as lack of disciplinary action and negligence or violation of personnel policies (Sauser, 2007; Miyaji, 2018). Rae and Subramaniam (2008) propose that an employee's ability and power to realize the weakness of her organization's system and to exploit the weakness by committing fraud. Further, Hooper and Pornelli (2010) emphasize that opportunity refers to two aspects, namely organizations' susceptibility to manipulation and a condition that facilitates fraud within organizations.

\subsection{Rationalization}

Fraudsters display certain mindsets that enable these individuals to rationalize their fraud (Hooper and Pornelli, 2010). Rasionalisasi adalah pembenaran perilaku curang karena kurangnya integritas pribadi, atau penalaran moral (Rae dan Subramaniam, 2008). Kecenderungan untuk melakukan suatu kecurangan bergantung pada nilai etika dan juga pada sikap pribadi para individu (Kenyon dan Tillton, 2006; Mikail \& Zainol 2018). Howe dan Malgwi (2006) berpendapat bahwa yang menghubungkan antara tekanan dan kesempatan saat seseorang dapat merasionalisasi perilaku curang tersebut (Jermsittiparsert \& Sriyakul, 2014; Mohajan, 2016).

\subsection{Machiavellianism}

Machiavellianism is a strategy of social behavior that involves the manipulation of other individuals for one's benefits (Wilson et al., 1996). Machiavellian individuals are considered manipulators and cheaters who erode the social capital of organizations or groups (Paulhus and Williams, 2002). Brown and Treviño (2006) suggest that Machiavellianism is negatively related to ethical leadership because Machiavellian individuals strongly express their attitude. The subordinates of fraudsters will also vividly experience the negative relationship between Machiavellianism and ethical leadership because they are often manipulated and cheated. Den Hartog and Belschak (2012) argue that Machiavellian individuals are skillful in forming alliances and collaborating with others to promote their self-interests. Machiavellian leaders are good liars who are masters in creating images they expect (DePaulo and Rosenthal, 1979).

\subsubsection{The Relationship Between Pressure and Fraud Intention}

Rae and Subramaniam (2008) suggest that pressure is related to employees' motivation to commit fraud as a consequence of their life pressure. Such pressure is so negative that individuals turn to be selfish. Pressure occurs because of inconvenient working situation and condition followed by employees' higher life demands. Pressure assumes that fraudsters have sufficient knowledge and opportunity to commit fraud. Individuals will commit fraud soon after they gain high trust position and have sufficient information on their firms. Thus, these individuals fully understand the success rate of their fraud plans. Fraudsters sometimes commit fraud to survive economically and politically or to fulfill their high desire to obtain power (Singleton and Singleton, 2011; Mujtaba \& Jamal 2018). Pressure that is related to individuals' personal life is usually triggered by financial problems that motivate fraudsters to commit fraud. Ineffective firms' or organizations' systems enable fraudsters to commit fraud. Based on previous studies, this study proposes the following first hypothesis:

H1: Individuals who are under high life pressure exhibit greater fraud intention than individuals who are under low life pressure. 


\subsubsection{The Relationship Between Opportunity and Fraud Intention}

Albrecht et al., (2004) show that fraudsters also have to have opportunities and right timing to commit fraud. Otherwise, they will likely fail to do so. Another perspective suggests that when having opportunities to commit fraud, fraudsters often give up resisting their pressure. Opportunities include weak internal control that results in lax situation and enables fraudsters to commit fraud (Ahmed, Mozammel \& Ahmed, 2018). Weak internal control is usually susceptible to fraud. Fraud that manages to leave no audit trail will make auditors find it difficult to trace. Also, weak internal control creates opportunities to commit fraud (Priantara, 2013; Mohamed, Rasheli \& Mwagike 2018). Based on previous studies, the following second hypothesis will be:

$\mathrm{H} 2$ : Individuals who are under weak internal control condition exhibit greater fraud intention than individuals with strong internal control condition.

\subsubsection{The Relationship Between Rationalization and Fraud Intention}

Individuals justify their illegal behavior to cover their action and to avoid sanction (Festinger, 1957). Rationalization emerges when internal auditors suspect employees or managers are committing fraud. Usually, internal auditors have collected sufficient evidence to support their suspicion, and they will interview the suspect employees. Fraudsters will then rationalize their actions to defend them from the suspicion or accusation of internal auditors. Rationalization also includes employees' or managers' dissatisfaction (J. W. Dorminey et al., 2010; Moussa, 2018) due to lack of recognition from their superiors although they have performed well. These employees will then commit deviant behavior in the form of fraud. When fraudsters commit fraud repeatedly they will justify the fraud they commit. Such justification will negatively impact other employees. Based on previous studies, we propose the following third hypothesis:

H3: Individuals with high rationalization on fraud will exhibit greater fraud intention than individuals with low rationalization.

\subsubsection{The Relationship Between Machiavellianism and Fraud Intention}

Simic et al., (2015) defines Machiavellian attitude as a personality dimension that reflects ignorance and individuals' strong will to achieve personal gains. Machiavellian individuals show a tendency to commit manipulative acts to other individuals' life. This attitude is detrimental in all professions because such individuals are selfish. Further, the attitude negatively affects organizational performance in achieving their goals. Such dysfunctional behavior manifests in various form, including fraud. A Machiavellian individual is likely to be mean and willing to deceive when making a relationship (Zin et al., 2011). Such deception will serve one's desire to manipulate others that harms other individuals. Based on previous findings, the study proposes the following fourth hypothesis:

H4: Individuals with high Machiavellian attitude will exhibit greater fraud intention than individuals with low Machiavellian attitude.

\section{Research Method}

\subsection{Research Design}

This study is a $3 \times 2 \times 2$ experiment method that combines between-subject and within-subject approaches with the factorial design. We organize our experimental study on paper and online modules. The independent variables of this study are pressure, opportunity, rationalization, and Machiavellian Trait while fraud intention is the dependent variable. Our subjects are accounting students who are assumed to be employees who work at a company. Accounting students have to have taken introductory auditing, auditing, and auditing practice courses and have a good understanding of the courses to qualify to be the research subjects. We argue that students can be our research subjects because the assignment of this experiment does not require specific skills or competence.

Table 1. The experiment matrix

\begin{tabular}{lllllll}
\hline & Pressure & \multicolumn{2}{c}{ Opportunity } & \multicolumn{2}{c}{ Rationalization } \\
\cline { 2 - 7 } & High & Low & High & Low & High & Low \\
\hline Mach (High) & $1_{\mathrm{A}}$ & $1_{\mathrm{B}}$ & $2_{\mathrm{A}}$ & $2_{\mathrm{B}}$ & $3_{\mathrm{A}}$ & $3_{\mathrm{B}}$ \\
\hline Mach (Low) & $4_{\mathrm{A}}$ & $4_{\mathrm{B}}$ & $5_{\mathrm{A}}$ & $5_{\mathrm{B}}$ & $6_{\mathrm{A}}$ & $6_{\mathrm{B}}$ \\
\hline
\end{tabular}




\subsection{Experimental Tasks and Procedure}

This study uses both paper and online modules. In the online module, subjects receive the module from a website that also informs the procedure to do the module. The rule stipulates that subjects will complete a question for 30 seconds and each correct answer subjects will receive a full score of ten. For each incorrect answer, subjects will have the second opportunity to answer the question and receive a score of five for a correct answer. If the answer is still incorrect, subjects will have the last chance and obtain a score of one.

We randomly divide subjects into six groups with different manipulation. In the online module, we distribute the website link to our research subjects that also contains the rules to complete the online module. Group 1 receives the manipulation of high Machiavellianism and high pressure (cell 1A) and low pressure (cell 1B). Next, group 2 receives high Machiavellianism and high opportunity (cell 2A) and low opportunity (cell 2B). Group 3 receives high Machiavellianism and high rationalization (cell 3A) and low rationalization (cell 3B). Group 4 receives low Machiavellianism and high pressure (4A) and low pressure (4B). Further, group 5 receives low Machiavellianism and high opportunity (5A) and low opportunity (5B). Lastly, group 6 receives low Machiavellianism and high rationalization (6A) and low rationalization (6B). These six groups are allocated to six different rooms, and then we distribute our modules according to their treatments. Afterward, subjects answer general questions related to audit that aim to test their understanding of audit concepts (10 multiple-choice questions). If subjects give the correct answers for more than $50 \%$ of the questions, they qualify for the next phase of the experiment. The test ensures that subjects' understanding of audit concepts does not affect their decisions. Next, we provide subjects with information on their role and tasks in the case as a manager of the purchasing division of a company. We test subjects' understanding of their role and tasks with five multiple-choice questions to ensure that they have internalized their tasks. Next, we provide subjects with a case that manipulates the independent variables and manipulation-check questions. After subjects complete their assignments, we collect the modules again (Ali \& Haseeb, 2019). Lastly, we debrief our subjects and return the situation and condition to normal and explain the objectives and benefits of this study.

\subsection{Technique of Analysis}

We initially run the manipulation check to determine which subjects qualify for the process. Next, we analyze the descriptive statistics and test the effectiveness of the randomization with One-Way Analysis of Variance (ANOVA). We also run the difference test for the results in the paper module and online module to ensure that the demographic factors (gender, sex, semester, and GPA) do not affect the results and only the manipulated variables affect fraud intention. Further, we test our hypotheses to investigate whether the four independent variables significantly affect fraud intention. Hypotheses are empirically supported if the probability is below 0.05 that indicates a significant difference.

\section{Results and Discussion}

\subsection{General Description of Subjects}

We run our experiment at the Faculty of Economics and Business of several universities. However, the paper-based test only takes place at the Satya Wacana Christian University, Salatiga. Meanwhile, we run the online experiment at ten universities, namely Satya Wacana Christian University (Salatiga), Sebelas Maret State University (Surakarta), STIE AUB (Surakarta), Atma Jaya University (Jogjakarta), Jogjakarta Technology University, Widya Mandala Catholic University (Surabaya), STIE Perbanas (Surabaya), Nusa Cendana University (Kupang), Indonesian Islam University (Jogjakarta), and Syah Kuala University (Banda Aceh). There are 352 students as the initial subjects that consist of 100 students completing the paper-based module and 252 students completing the online module. Further, 309 subjects pass the manipulation check. We generate four demographic characteristics of each subject, namely sex, age, grade point average (GPA), and semester. Subjects are accounting students who have taken auditing, internal auditing practice, and professional ethics courses. Table 2 below displays the profiles of subjects who participate in this study:

Table 2. Subjects' profiles

\begin{tabular}{lll}
\hline Explanation & Total & Percentage \\
\hline Sex & & \\
\hline Male & 81 & $26.2 \%$ \\
\hline
\end{tabular}




\begin{tabular}{lll}
\hline Female & 221 & $73.8 \%$ \\
\hline Age & & \\
\hline$<\mathbf{1 9}$ & 49 & $15.8 \%$ \\
\hline $\mathbf{2 0}$ & 98 & $31.7 \%$ \\
\hline$>\mathbf{2 1}$ & 155 & $52.5 \%$ \\
\hline Grade Point Average (GPA) & & \\
\hline$<\mathbf{2 . 0 0}$ & 1 & $0.3 \%$ \\
\hline $\mathbf{2 . 0 1}-\mathbf{2 . 9 9}$ & 34 & $11.0 \%$ \\
\hline $\mathbf{3 . 0 0}-\mathbf{3 . 4 9}$ & 133 & $43.0 \%$ \\
\hline $\mathbf{3 . 5 0}>$ & 134 & $45.7 \%$ \\
\hline Semester & & \\
\hline $\mathbf{1 - 4}$ & 86 & $27.8 \%$ \\
\hline $\mathbf{5 - 6}$ & 160 & $51.8 \%$ \\
\hline $\mathbf{7 - 8}$ & 56 & $20.4 \%$ \\
\hline
\end{tabular}

Source: Processed primary data, 2018

Table 2 informs that there are 81 (26.2\%) male subjects while there are 221 female subjects (73.8\%). More than half of the subjects ( 155 or $52.5 \%$ of the total subjects) are 21 years old or older. Further, 124 subjects (45.7\%) have a GPA higher than 3.50. Lastly, 160 subjects $(51.8 \%)$ are in their second study years in the second semester of the 2017/2018 academic year.

\subsection{Manipulation Check}

We check our manipulation after collecting all research data. Initially, 352 students participate in this study. Our manipulation check indicates that 309 subjects qualify for further analysis. Specifically, subjects pass the manipulation check if their scores are higher than the theoretical score for each variable. Subjects who score below 50 do not pass the manipulation check while those who score above 50 pass the manipulation check. The theoretical score in the manipulation module ranges from 10 to 100.

\subsection{Randomization Test}

We then test the effectiveness of our randomization on subjects' profiles with One-Way ANOVA. This test investigates whether the four demographic variables (sex, age, GPA, and semester) affect subjects' fraud intention. Table 3 demonstrates that the significance values of the four demographic variables are greater than alpha $(0.05)$.

Table 3. The results of one-way ANOVA

\begin{tabular}{llll}
\hline & Mean Square & Sig. & Explanation \\
\hline Sex & & & \\
\hline Between Groups & 211.449 & 0.558 & No effect \\
\hline Within Groups & 613.619 & & \\
\hline Age & & & \\
\hline Between Groups & 94.241 & 0.858 & No effect \\
\hline Within Groups & 615.748 & & \\
\hline Grade Point Average (GPA) & & & \\
\hline Between Groups & 426.671 & 0.556 & No effect \\
\hline Within Groups & 614.151 & & \\
\hline
\end{tabular}




\begin{tabular}{llll}
\hline Semester & & & \\
\hline Between Groups & 371.749 & 0.546 & No effect \\
\hline Within Groups & 613.891 & & \\
\hline
\end{tabular}

Source: Processed primary data, 2018

Table 3 above suggests that the four demographic characteristics (sex, age, GPA, and semester) do not affect subjects' fraud intention. Thus, our randomization is effective because only our treatments (fraud triangle and Machiavellianism) affect subjects' fraud intention

Next, we test the difference of fraud intention of subjects with paper-based experiment and those with website-based experiment. As indicated by Table 4, the significance value of the difference is 0.073 ( $p>0.05)$, thus suggesting that the different modes of the experiment do not affect the manipulation process of this experiment.

Table 4. The results of the randomization test of data generation method

\begin{tabular}{lllll}
\hline & Mean & Std. Deviation & t & Sig. (2-tailed) \\
\hline Method of Generating Data & & & & \\
\hline Website & 62.72 & 23.773 & & \\
\hline & & & 1.800 & 0.073 \\
\hline Paper & 57.61 & 25.459 & &
\end{tabular}

Source: Processed primary data, 2018

\subsection{Test of Hypothesis 1}

\subsubsection{The Relationship Between Pressure and Fraud Intention}

Hypothesis 1 predicts that the greater subjects' life pressure, the higher is their fraud intention relative to subjects with low pressure. We test this hypothesis with the sample t-test with four independent groups. Group 1 and group 2 (group 3 and 4) receive high (low) life pressure treatment.

Table 5. The results of the test of hypothesis 1

\begin{tabular}{lcccc}
\hline & Mean & Std. Deviation & t & Sig. (2-tailed) \\
\hline Pressure & & & & \\
\hline High & 70.20 & 15.611 & & \\
\hline & & & 2.545 & 0.012 \\
\hline Rendah & 58.93 & 27.348 & &
\end{tabular}

Source" Processed primary data, 2018

Table 5 explains that the average fraud intention of subjects with high (low) life pressure is 70.20 (58.93). Our t-test for Equality of Means indicates the significance value (equal variances assumed) of $0.012(<0.05)$, suggesting that individuals with high life pressure exhibit greater fraud intention than individuals with low life pressure. When managers of the purchasing division are under high life pressure from their families, it is likely that their assessment of the offers from new vendors are affected that will result in a tension between values and ethics and eventually create fraud. Higher pressure reduces the ability of moral reasoning to assess the existing moral dilemmas. Thus, individuals with high pressure are likely to commit actions that violate professional standards because they have less power to resist the actions. The results are in line with Ruankaew (2016) who defines pressure as an urge that motivates individuals to commit unethical behavior. Unethical behavior potentially creates fraud intention as an ethics violation. Our findings also support Coleman (1987) who propose that the desire to gain more money is an obvious motivation of most fraudsters. 
When individuals have higher pressure, they are more likely to commit fraud. The magnitude of the pressure is heavily affected by the perceived needs of money to fulfill individuals' needs. Fraudsters who commit more severe fraud aim to satisfy more needs in their life. Thus, ones have to control themselves to avoid committing fraud.

\subsection{Test of Hypothesis 2}

\subsection{The Relationship Between Opportunity and Fraud Intention}

Hypothesis 2 predicts that subjects with weak internal control system treatment exhibit greater fraud intention than subjects with a strong internal control system. We test this hypothesis with the sample t-test with four independent groups. Group 5 and group 6 (group 7 and 8 ) receive a weak (strong) internal control system.

Table 6. The results of the test of hypothesis 2

\begin{tabular}{lclll}
\hline & Mean & Std. Deviation & T & Sig. (2-tailed) \\
\hline Opportunity & & & & \\
\hline High & 50.67 & 27.253 & & \\
\hline & & & -2.420 & 0.017 \\
\hline Rendah & 63.39 & 26.547 & &
\end{tabular}

Source: Processed primary data, 2018

Table 6 suggests that the average fraud intention when the internal control system is weak (strong) is 27.253 (26.547). Our the t-test for Equality of Means results in the significance value (equal variances assumed) of $0.017 \quad(<0.05)$, suggesting that individuals who are under weak internal control system exhibit greater fraud intention than individuals with strong internal control system.

When managers and employees are aware of the weakness of their firms' internal control, they may exploit the weakness to commit fraud. Further, weak internal control system arguably disrupts divisional operations, including those in the purchasing division. The awareness of the weakness of their firms' internal control may affect managers' assessment on new vendors' offers that will result in a tension between values and ethics and eventually create fraud. Thus, weak internal control system increases the opportunity to commit fraud that violates professional standards because they do not have the power to resist the actions.

Our results are also in line with Dorminey et al. (2012) who argue that perceived opportunity is a perception that there is weak control and the possibility of being detected is remote. Consequently, perceived opportunity needs the ability to act without being detected. In the accounting literature, opportunity exists because of a weak internal control system. The findings are also supported by Lokanan (2015) who explains that opportunity is the main factor that creates fraud.

The ineffectiveness of internal control is also an opportunity for firms to commit fraud. When firms have strong internal control, they have less opportunity to commit fraud and eventually their opportunity to commit fraud declines. Thus, opportunity positively affects fraud intention. When the ability to commit fraud disappears because of highly reduced opportunity, ones cannot act as they wish. The absence of opportunity prevents firms from committing fraud and reduces fraud intention.

\subsection{Test of Hypothesis 3}

\subsubsection{The Relationship Between Rationalization and Fraud Intention}

Hypothesis 3 predicts that the higher subjects' rationalization, the higher is their fraud intention relative to subjects who receive the low rationalization treatment. We test this hypothesis with sample t-test with four independent populations. Group 9 and group 10 receive the high rationalization treatment and group 11 and 12 receive the low rationalization treatment. 
Table 6. The results of the test of hypothesis 3

\begin{tabular}{lcccc}
\hline & Mean & Std. Deviation & t & Sig. (2-tailed) \\
\hline Rationalization & & & & \\
\hline High & 64.08 & 22.526 & & \\
\hline & & & -3.019 & 0.003 \\
\hline Low & 50.24 & 20.908 & & \\
\hline
\end{tabular}

Source: Processed primary data, 2018

Table 7 explains that the average fraud intention of individuals with high (low) rationalization is 64.08 (50.24). Our t-test for Equality of Means results in the significance value (equal variances assumed) of $0.003(<0.05)$, suggesting that individuals with high rationalization exhibit greater fraud intention than those with low rationalization.

High rationalization due to organization culture motivates managers to commit fraud that violates professional standards because they do not have the power to resist the actions. Our results are in line with Dorminey et al. (2010) who reveal that fraudsters sometimes do not perceive their actions to be unethical; they only justify their actions as ethical before fraud takes place. This attitude exists when fraudsters are accustomed to the organization culture of previous managers or individuals who created the culture that unintentionally creates fraud. The findings are also supported by Maragno \& Borba (2017) who document that in the fraud triangle context, fraudsters use rationalization to justify illegal or unethical acts that have negative connotations.

Managers try to justify several accounting practices because of the immaterial impacts of these practices. Managers can also justify fraud they commit by emphasizing the immaterial effect of the fraud. For example, managers can identify revenues that should be unrecognized because their impacts are not material. Rationalization often becomes individuals' requests to justify fraud. When rationalization exists, the probability of firms to find fraud intention is high.

\subsection{Test of Hypothesis 4}

\subsubsection{The Relationship Between Machiavellianism and Fraud Intention}

Hypothesis 4 predicts that individuals with higher Machiavellianism exhibit greater fraud intention than subjects with low Machiavellianism. We test this hypothesis with the sample t-test with 12 independent populations. Six groups receive the high Machiavellianism treatment: group 1 (high life pressure), group 3 (low life pressure), group 5 (weak internal control system), group 7 (strong internal control system), group 9 ( high rationalization), and group 11 (low rationalization). The other six groups receive the low Machiavellianism treatment: group 2 (high life pressure), group 4 (low life pressure), group 6 (weak internal control system), group 8 (strong internal control system), group 10 (high rationalization), and 12 (low rationalization).

Table 8 . The results of the test of hypothesis 4

\begin{tabular}{lcccc}
\hline & Mean & Std. Deviation & T & Sig. (2-tailed) \\
\hline Machiavellianism & & & & \\
\hline High & 74.06 & 20.205 & & \\
\hline & & & 10.498 & 0.000 \\
\hline Low & 48.35 & 21.995 & & \\
\hline
\end{tabular}

Source: Processed primary data, 2018

Table 8 explains that the average fraud intention of subjects with high (low) Machiavellianism is 74.06 (48.35). Our t-test for Equality of Means indicates the significance value of $0.000(<0.01)$, suggesting that individuals with high Machiavellianism exhibit greater intention than individuals with low Machiavellianism. When the managers of purchasing divisions exhibit high Machiavellianism from their own characters, they tend to prioritize themselves when making decisions and use any possible way to benefit themselves. Also, high Machiavellianism likely affects managers' assessment of new vendors' offer that will result in a tension between values and ethics and eventually 
create fraud. Individuals with high Machiavellianism exhibit greater fraud intention than those with low Machiavellianism and they will act not by professional standards because they have less power to resist the actions.

Our results are in line with Hartmann and Maas (2010) who argue that organizations have to hire employees with low Machiavellianism to ensure strong internal control. Individuals with high Machiavellianism potentially harm their environments and surrounding people because they are more likely to commit fraud. The findings are also supported by Hawley (2003) who show that selfish Machiavellian individuals are motivated by their objectives. They are also easily adaptable and better able to display their positive image that benefits themselves. Machiavellian individuals can implement pro-social and coercive strategies to pursue their interests and act cooperatively and friendly. These behaviors also appear in individuals with low Machiavellianism that fraudsters can exploit such behaviors to commit fraud.

\section{Conclusion, Limitation, and Suggestion}

\subsection{Conclusion}

This study tests fraud intention with Machiavellianism, together with pressure, opportunity, and rationalization, as the independent variable. Our results offer several conclusions. First, individuals who are under high life pressure exhibit greater fraud intention than individuals with low life pressure. Second, individuals who are under weak internal control exhibit greater fraud intention than individuals with strong internal control.

Third, individuals with high rationalization of fraud exhibit greater fraud intention than individuals with low rationalization. Fourth, individuals with high Machiavellianism exhibit greater fraud intention than individuals with low Machiavellianism.

\subsection{Limitation and Suggestion}

A limitation of this study is that our online experiment is less optimal due to the problems with the browser and other electronic media. Further, the completion of the paper-based modules takes place at different times with short break times to ensure that the results are more accurate. We advise future studies to operationalize other characteristics other than Machiavellianism.

\section{References}

Abdullahi, R. U., \& Mansor, N. (2015). Fraud Triangle Theory and Fraud Diamond Theory. Understanding the Convergent and Divergent For Future Research. International Journal of Academic Research in Accounting Finance and Management Sciences. https://doi.org/10.6007/IJARAFMS/v5-3/1823

ACFE. (2018). Report of the Nation: Global Study on Occupational Fraud and Abuse. Inc. ACFE.

Ahmed, U., Mozammel, S., \& Ahmed, H. (2018). Performance on the road: examining the critical role of training effectiveness amongst the blue-collar employees in Bahrain. Asian Journal of Empirical Research, 8(9), 342-351.

Albrecht, W. S., Albrecht C. C., \& Albrecht, C. O. (2004). Agency Theory fraud and corporate. Journal of Forensic Accounting.

Ali, A., \& Haseeb, M. (2019). Radio frequency identification (RFID) technology as a strategic tool towards higher performance of supply chain operations in textile and apparel industry of Malaysia. Uncertain Supply Chain Management, 7(2), 215-226.

Brown, M. E., \& Treviño, L. K. (2006). Ethical leadership: A review and future directions. The Leadership Quarterly. https://doi.org/10.1016/j.leaqua.2006.10.004

Clinard, M. B., \& Cressey, D. R. (1954). Other People's Money: A Study in the Social Psychology of Embezzlement. American Sociological Review. https://doi.org/10.2307/2087778

Coleman, J. W. (1987). Toward an Integrated Theory of White-Collar Crime. American Journal of Sociology. https://doi.org/10.1086/228750

Den Hartog, D. N., \& Belschak, F. D. (2012). Work Engagement and Machiavellianism in the Ethical Leadership Process. Journal of Business Ethics. https://doi.org/10.1007/s10551-012-1296-4

DePaulo, B. M., \& Rosenthal, R. (1979). Telling Lies. Journal of Personality and Social Psychology. https://doi.org/10.1037/0022-3514.37.10.1713

Dorminey, J. W., Fleming, A. S., Kranacher, M.-J., \& Riley Jr., R. A. (2010). Beyond the Fraud Triangle (cover story). CPA Journal. 
Dorminey, J., Scott Fleming, A., Kranacher, M. J., \& Riley, R. A. (2012). The evolution of fraud theory. Issues in Accounting Education. https://doi.org/10.2308/iace-50131

Festinger, L. (1957). A theory of cognitive dissonance. Scientific American. https://doi.org/10.1037/10318-001

Ghosh, D., \& Crain, T. L. (1996). Experimental Investigation of Ethical Standards and Perceived Probability of Audit on Intentional Noncompliance. Behavioral Research in Accounting.

Gunnthorsdottir, A., McCabe, K., \& Smith, V. (2002). Using the Machiavellianism Instrument to Predict Trustworthiness in a Bargaining Game. Journal of Economic Psychology, 23(1), 49-66.

Hartmann, F. G. H., \& Maas, V. S. (2010). Why business unit controllers create budget slack: Involvement in management, social pressure, and Machiavellianism. Behavioral Research in Accounting. https://doi.org/10.2308/bria.2010.22.2.27

Hawley, P. H. (2003). Prosocial and Coercive Configurations of Resource Control in Early Adolescence: A Case for the Well-Adapted Machiavellian. Merrill-Palmer Quarterly. https://doi.org/10.1353/mpq.2003.0013

Hooper, M. J., \& Pornelli, C. M. (2010). Deterring and Detecting Finacial Fraud: a Platform for Action. Retrieved March 15, 2018, from https://www.thecaq.org/Docs/Reports-And-Publications/Deterring-And-Detecting Financial-Reporting-Fraud-A-Platform-For-Action.Pdf

Houck, M. M., Kranacher, M.-J., Morris, B., Riley, R. A. Jr., Robertson, J., \& Wells, J. T. (2006). Forensic Accounting as an Investigative Tool. CPA Journal.

Howe, M. A., \& Malgwi, C. A. (2006). Playing the Ponies: A \$5 Million Embezzlement Case. Journal of Education for Business. https://doi.org/10.3200/JOEB.82.1.27-33

Jermsittiparsert, K., \& Sriyakul, T. (2014). The Development of Population Potential and National Power by Elevating the Professional Standard for Sport Coaches. Asian Social Science, 10(10), 188-198.

Kenyon, W., \& Tillton, P. D. (2006). Potential Red Flags and Fraud Detection Techniques: A Guide to Forensic Accounting Investigation (First). New Jersey: John Wiley Sons Inc. https://doi.org/10.1002/9781119200048.ch13

Lister, L. M. (2007). A practical approach to Fraud Risk. Internal Auditor.

Lokanan, M. E. (2015). Challenges to the fraud triangle: Questions on its usefulness. Accounting Forum. https://doi.org/10.1016/j.accfor.2015.05.002

Maragno, L. M. D., \& Borba, J. A. (2017). Conceptual map of fraud: theoretical and empirical configuration of international studies and future research opportunities. Journal of Education and Research in Accounting.

Mbunda-Nekang, F. M. (2018). Preventing Conflict and Ensuring National Peace through Folklore: Option for Cameroon. International Journal of English Language and Literature Studies, 7(2), 22-31.

Michael, O., Justina, O., \& Olabode, D. (2018). Child Labour and Protection: An Exploration of Vulnerable Children in Lagos State, Nigeria. Humanities and Social Sciences Letters, 6(4), 171-179.

Mikail, A., \& Zainol, Z. A. (2018). Conservation of Biodiversity in Sub Sahara Africa: Prospecting for Genetic Resources and Traditional Knowledge Regulation in Ethiopia. International Journal of Asian Social Science, $8(9), 725-734$.

Miyaji, I. (2018). Comparison of Useful Activities of Improving Awareness in Blended Classes in Java Script and PHP Programming. International Journal of Educational Technology and Learning, 3(2), 78-92.

Mohajan, H. K. (2016). Knowledge is an Essential Element at Present World. International Journal of Publication and Social Studies, 1(1), 31-53.

Mohamed, B. M., Rasheli, G. A., \& Mwagike, L. R. (2018). Marginal Effects of Factors Influencing Procurement Records Management: A Survey of Selected Procuring Entities in Tanzania. International Journal of Social and Administrative Sciences, 3(1), 22-34.

Moussa, A. (2018). Does Agricultural Sector Contribute to the Economic Growth in Case of Republic of Benin?. Journal of Social Economics Research, 5(2), 85-93.

Mujtaba, M., \& Jamal, S. (2018). Enhancing Work Climate to Improve the Perceived Performance Leading to Talent Retention-A Study of Pakistani Service Sector. International Journal of Social Sciences Perspectives, 3(1), 21-33. 
Paulhus, D. L., \& Williams, K. M. (2002). The Dark Triad of personality: Narcissism, Machiavellianism, and psychopathy. Journal of Research in Personality. https://doi.org/10.1016/S0092-6566(02)00505-6

Priantara, D. (2013). Fraud Auditing \& Investigation. Jakarta: Mitra Wacana Media.

Rae, K., \& Subramaniam, N. (2008). Quality of internal control procedures: Antecedents and moderating effect on organisational justice and employee fraud. Managerial Auditing Journal. https://doi.org/10.1108/02686900810839820

Rezaee, Z. (2005). Causes, consequences, and deterrence of financial statement fraud. Critical Perspectives on Accounting. https://doi.org/10.1016/S1045-2354(03)00072-8

Ruankaew, T. (2016). Beyond the Fraud Diamond. International Journal of Business Management \& Economic Research.

Sauser, W. (2007). Employee Theft: Who, How, Why, and What Can Be Done. SAM Advanced Management Journal, 3(72), 13-25.

Simic, I., Matovic, I. M., \& Stojkovic, N. (2015). Analysis of Machiavellian Behavior of Students in The Republic of Serbia. Economics and Organization, 12(3), 199-208.

Singleton, T. W., \& Singleton, A. J. (2011). Fraud Auditing and Forensic Accounting (4th ed.). https://doi.org/10.1002/9781118269183

Tang, T. L.-P., \& Chen, Y.-J. (2008). Intelligence vs. Wisdom: the Love of Money, Machiavellianism. Journal of Business Ethics, 82, 1-26

Wilson, D. S., Near, D., \& Miller, R. R. (1996). Machiavellianism: A synthesis of the evolutionary and psychological literatures. Psychological Bulletin. https://doi.org/10.1037/0033-2909.119.2.285

Zin, S. M., Ahmad, N., Ngah, N. E., Ismail, R., Ibrahim, N., \& Abdullah, I. H. T. (2011). Effects of Machiavellianism on Ingratiation in Organizational Settings. Canadian Social Science. https://doi.org/10.3968/j.css.1923669720110702.025 